PRINT ISSN 1119-8362

Electronic ISSN 1119-8362
Full-text Available Online at https://www.ajol.info/index.php/jasem http://ww.bioline.org.br/ja
J. Appl. Sci. Environ. Manage. Vol. 23 (7) 1353-1356 July 2019

\title{
Effect of pH and Hypo-Osmotic Stress on NaCl Electrolyte Permeation across Red Blood Cell Membrane
}

\author{
${ }^{1}$ ATOLAIYE, BO; ${ }^{1 *}$ EDWARD-EKPU, DU; ${ }^{2}$ BAMIDELE, TO \\ ${ }^{I}$ Department of Chemistry, ${ }^{2}$ Department of Biochemistry and Molecular Biology, Nasarawa State University, Keffi, Nigeria \\ *Corresponding Author Email: uwagbalae@gmail.com
}

\begin{abstract}
The study compares the effects produced by $\mathrm{H}^{+}$concentrations in hypo-osmotically stressed $\mathrm{NaCl}$ solutions on permeation through $\mathrm{RBC}$ membrane. Iso-osmotic solutions of $\mathrm{NaCl}(160 \mathrm{mM})$ were prepared taking into account their molecular weight and osmotic concentration. Iso-osmotic solutions $(25 \mathrm{~mL})$ were diluted with $25 \mathrm{~mL}$ of distilled water to give half the initial concentrations (50\% hypotonic salt solutions). Hypotonic $\mathrm{NaCl}$ solutions of $\mathrm{pH}$ of $6.2,6.8,7.4$ and 8.0 were prepared, mixed with $0.05 \mathrm{~mL}$ of $\mathrm{RBC}$ suspension and their absorbance/min for 16 min were measured using a UV/Visible spectrophotometer while the RBCs haemolyse. $\mathrm{H}^{+}$ concentration and hence $\mathrm{pH}$ was found to have a significant effect on ion permeability through RBC membrane. Permeation occurred faster in alkalinic solutions under hypo-osmotic stress. Permeation increased with every increase in $\mathrm{pH}$ and the increase is steeper at $\mathrm{pH} 7.4-8.0$.
\end{abstract}

DOI: https://dx.doi.org/10.4314/jasem.v23i7.25

Copyright: Copyright (C) 2019 Atolaiye et al. This is an open access article distributed under the Creative Commons Attribution License (CCL), which permits unrestricted use, distribution, and reproduction in any medium, provided the original work is properly cited.

Dates: Received: 04 May 2019; Revised: 02 June 2019; Accepted 10 July 2019

Keywords: Ions, Electrolyte, Permeability, Red Blood Cell, Membrane

Electrolytes, when dissolved in suitable ionizing solvent like water ionizes (dissociates) into cations and anions and the $\mathrm{H}^{+}$ion concentration $(\mathrm{pH})$ of the electrolyte solution can be increased or decreased using a buffer (Okolue et al., 2014). Ions enter and leave cells through the cell membrane which is a selective barrier and has a dynamic structure composed of two layers of phospholipid molecules interspersed with cholesterol and proteins. It regulates passage of water and ions through it (Yawata, 2003). The type of ions or electrolyte that is allowed to pass through a cell membrane and at what rate can be determined by certain physical, chemical and physiological factors (Sowemimo-Coker, 2002; Nepal and Rao, 2011).

Among all the models used to study membrane transport, Red Blood Cells (RBCs) have probably been the most utilised cell type. Isosmotic haemolysis, ion content analysis, or fluorescence techniques have been widely used to characterise the various transporters present in the RBC membranes (Bouyer et al., 2012). Chemical phenomenon (dissociation and ionisation); physiological phenomenon (haemolysis); physical properties (refractive index, dispersion or absorption of light) and optical density/turbidity (light scattering), have been used to study the electrochemical effects of individual electrons and protons on cell membrane, the relationships correlating the number and energy states of electrons in ions and electrolytes with the observable properties shown by a cell system (Sherwood et al., 2013; Nepal and Rao, 2011; Sowemimo-Coker, 2002; Benga, 1989; Bakko, 1985).

Haemolysis of RBC is accompanied by changes in refractive index or light absorbance of the cell suspensions. In the process of haemolysis, the turbidity (light scattering) of the RBC suspension itself decreases, causing a decrease in absorbance of the non-centrifuged cell suspension at $600 \mathrm{~nm}$ (Strand, 1983; Abramoff and Thomson, 1986; Manalis, 1996; Rasia \& Bollini, 1998; Nepal and Rao, 2011). The amount of time that it takes for haemolysis or crenation to occur is directly related to the rate of permeation across the cell membrane. Therefore, the rate of haemolysis can also be used as an indicator of the permeability for a particular penetrating solutes (Bakko, 1985; Giese, 1963; Sowemimo-Coker, 2002).

The $\mathrm{pH}$ in mammals varies from compartment to compartment with blood having a natural $\mathrm{pH}$ range of 7.34 -7.45 (Boron and Boulpaep, 2004). Experimental studies show that $\mathrm{pH}$ have a marked influence on ion transport rate as observed by Ramirez et al. (1999), Chen et al. (1994) and Akerman et al. (1998) who 
carried out studies using fixed charge membrane, silk fibroin membranes and porous ion exchange membrane respectively. Fluxes measured in sodium low ionic solution medium were increased modestly at pH7.4 and decreased at pH 6.1 (Bernhardt et al, 1991). A drop in the rate of permeation of ions at $\mathrm{pH}$ of 4 was reported for a polymeric membrane which was attributed to the interference of the hydrogen ion $\left[\mathrm{H}^{+}\right]$ with the electrolyte solution and thus retarding the rate of permeation. A slight increment was also observed in alkaline medium of $\mathrm{pH} 11$ (Okolue et al., 2014). An increase in $\mathrm{pH}$ leads to an increased efflux at a given ionic strength, but the size of the $\mathrm{pH}$ effect is small at low ionic strength.

This study is aimed at providing information on how $\mathrm{pH}$ and hypo-osmotic stress affect the rate of haemolysis of RBC of goat and hence ion permeation across the cell membrane. Sodium chloride $(\mathrm{NaCl})$ solution plays a major role in the cellular response to the extracellular environment (Kee and Paulanka, 1994), being the primary electrolyte in many extracellular solutions, both in vivo (plasma) and ex vivo (phosphate buffered saline solutions), hence its use in this study. The objective of this study is to compare the rate at which ions of hypotonic $\mathrm{NaCl}$ permeate through $\mathrm{RBC}$ membrane and to compare the effects produced by $\mathrm{H}^{+}$concentrations variation $(\mathrm{pH}$ : 6.2 6.8,7.4 and 8.0) in the hypo-osmotically stressed $\mathrm{NaCl}$ solutions on permeation through $\mathrm{RBC}$ membrane. This research is necessary to understand or predict how cells respond to a changing extracellular environment, brought on by $\mathrm{pH}$, tonicity and osmotic variations.

\section{MATERIALS AND METHODS}

The method and principle adopted in this work are in accordance with those used by Manalis (1996), Rasia \& Bollini (1998) and Nepal \& Rao (2011). Iso-osmotic solutions of $\mathrm{NaCl}(160 \mathrm{mM})$ were prepared taking into account their molecular weight and osmotic concentration. Iso-osmotic solutions $(25 \mathrm{~mL})$ were diluted with $25 \mathrm{~mL}$ of distilled water to give half the initial concentrations (50\% hypotonic salt solutions). hypotonic $\mathrm{NaCl}$ solutions of 4 different $\mathrm{pH}$ were prepared by adding isotonic sodium phosphate buffers to the hypotonic $\mathrm{NaCl}$ solutions to give a $\mathrm{pH}$ of 6.2 , 6.8, 7.4 and 8.0. The final $\mathrm{pH}$ was adjusted using a Jenway (Model 430) pH/conductivity. Blood (20 mL) collected in acid-citrate-dextrose (ACD) was washed thrice with isotonic saline and the RBC separated. Each hypotonic solution $(1.5 \mathrm{~mL})$ prepared was mixed with $0.05 \mathrm{~mL}$ of $\mathrm{RBC}$ suspension and their absorbance/min for 16 min were measured using a $\mathrm{UV} / \mathrm{V}$ is spectrophotometer (722-2000 20D) set at 600 $\mathrm{nm}$ while the RBCs haemolyse. The absorbance of each solution were recorded. The data were used to plot graphs with the time $(\mathrm{min})$ on the $\mathrm{x}$-axis and the absorbance $(\AA)$ on the y-axis. Logarithmic trendlines were used to analyse the graph to understand the correlationship and the interrelationship of the variables of this study.

\section{Results and Discussion}

Figure 1 shows a graphical presentatiion of the absorbance recoeded againts time. The graph shows the changes in absorbance of the RBC+Electrolyte solutions of $\mathrm{pH} 6.2,6.8,7.4$ and 8.0 after 16 minutes of haemolysis. The graph showed that the absorbance of all the RBC+Electrolyte solutions reduced with time and the reduction was more gradual at higher $\mathrm{pH}$ (7.4 and 8.0). The max/min absorbance values of the various RBC+Electrolyte solutions was observed to be higher with high $\mathrm{pH}$ and lower with low $\mathrm{pH}$. At 0 and $16 \mathrm{~min}$ of the haemolysis the $\mathrm{RBC}+$ Electrolyte solutions of $\mathrm{pH} 6.2,6.8,7.4$ and 8.0 showed an increasing $\mathrm{max} / \mathrm{min}$ absorbance of $0.154 / 0.043$, $0.209 / 0.074$. $0.225 / 0.082$ and $0.328 / 0.138$ respectively.

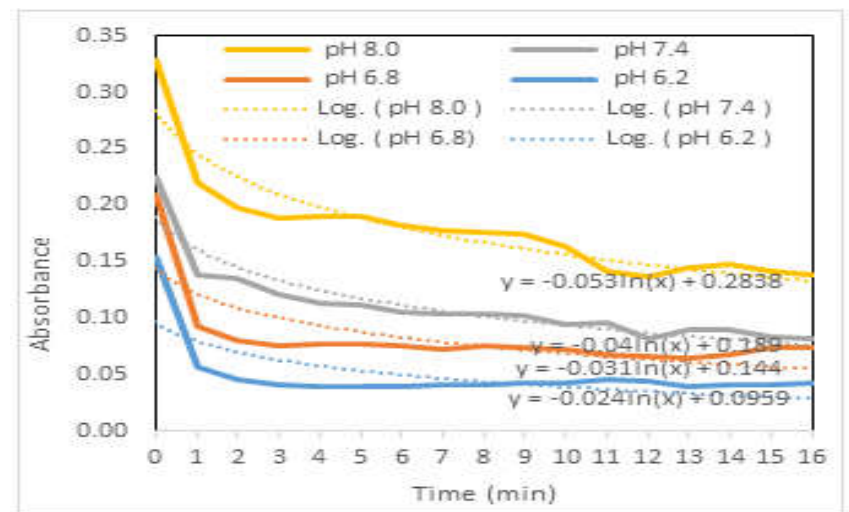

Fig 1: A graphical presentation of the changes in absorbance of the $\mathrm{RBC}+$ Electrolyte solutions of $\mathrm{pH}$ 6.5. 7.4, 6.8 and 8.0 after 16 minutes of haemolysis

ATOLAIYE, BO; EDWARD-EKPU, DU; BAMIDELE, TO 
Table 1: Changes in absorbance of the RBC+Electrolyte solutions after 16 minutes of haemolysis*

\begin{tabular}{llcccc}
\hline & $y=m x+c$ & $\begin{array}{c}y 1 \\
(x=1)\end{array}$ & $\begin{array}{c}y 2 \\
(x=17)\end{array}$ & $\begin{array}{c}\text { Av } \\
\left(y_{1}-y_{2}\right)\end{array}$ & $\begin{array}{c}\text { Increase } \\
\text { in Ay }\end{array}$ \\
\hline pH 8.0 & $y=-0.053 \ln (x)+0.2838$ & 0.284 & 0.134 & 0.150 & - \\
pH 7.4 & $y=-0.04 \ln (x)+0.189$ & 0.189 & 0.076 & 0.113 & 0.037 \\
pH 6.8 & $y=-0.03 \ln (x)+0.144$ & 0.144 & 0.056 & 0.088 & 0.025 \\
pH 6.2 & $y=-0.024 \ln (x)+0.0959$ & 0.096 & 0.028 & 0.068 & 0.020 \\
\hline
\end{tabular}

*Deduced from the logarithmic trendline of the graphic interpretation of the experiment's data

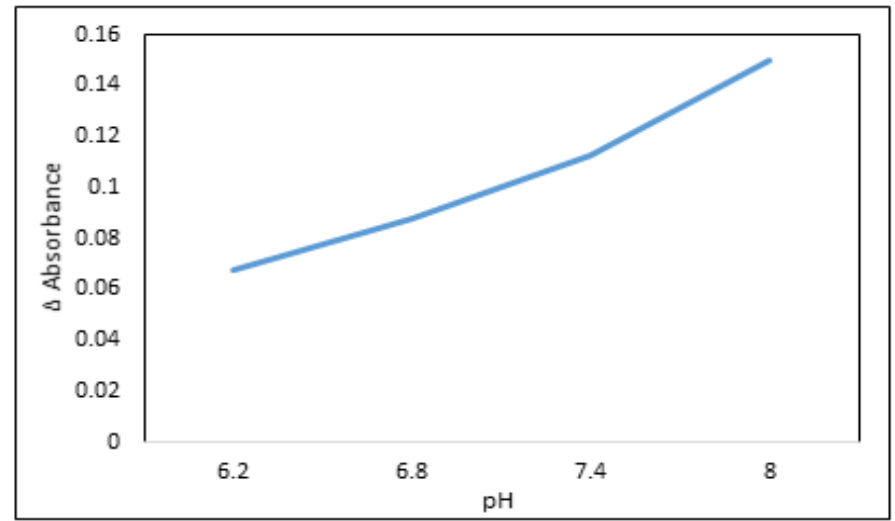

Fig 2: Changes in $\triangle$ absorbance of the $\mathrm{RBC}+$ Electrolyte solutions with change in $\mathrm{pH}$

Table 1 shows the changes in absorbance of the $\mathrm{RBC}+$ Electrolyte solutions after 16 minutes of haemolysis deduced from the logarithmic trendline of the graph of the experiment's data (Fig: 1). The result in the table shows that as separately observed by Ramirez et al. (1999), Chen et al. (1994), Akerman et al. (1998) and Bernhardt et al. (1991) in their various studies, $\mathrm{pH}$ has an influence on ion transportation across RBC membranes. It was observed that there was a decrease in $\Delta$ absorbance $(0.150-0.068)$ with increase in $\mathrm{H}^{+}$concentration $(\mathrm{pH} 8.0-6.2)$ of $\mathrm{NaCl}$ as shown in Figure 1, Figure 2 and Table 1, similar to observations reported by Bernhardt et al. (1991) and (Okolue et al., 2014). The difference between absorbance increased with each increase in $\mathrm{pH}$. There was a steeper increase by 0.037 in $\Delta$ absorbance from $\mathrm{pH} 7.4-8.0$ compared to 0.025 and 0.020 increase of $\Delta$ absorbance from $\mathrm{pH} 6.8-7.4$ and $\mathrm{pH} 6.2-6.8$ respectively. This means haemolysis hence permeation occurs faster in alkalinic solutions under hypo-osmotic stress.

Conclusion: The study showed that $\mathrm{H}^{+}$concentration and hence $\mathrm{pH}$ has a significant effect on ion permeability through $\mathrm{RBC}$ membrane. Change in absorbance increased with every increase in $\mathrm{pH}$ and the increase was steeper at $\mathrm{pH} 7.4-8.0$. Permeation was found to occur faster in alkalinic solutions under hypo-osmotic stress.

\section{REFERENCES}

Abramoff, P; Thomson, RG (1982). Movement of materials through cell membranes. In Freeman, WH (ed.) Laboratory outlines in biology, New York. pp. 109-121.

Akerman, S (1998). Transport of drugs across porous ion exchange membranes. J. Control Release 50:153-166.

Bakko, EL (1985). Cell membrane physiology. Physiology laboratory manual (unpublished). St. Olaf College, Northfield, Minnesota.

Benga, G (1989). Water exchange through the erythrocytes membrane. Int. Rev. Cytol. 114:273-318.

Bernhardt, I; Hall, AC; Ellory, JA (1991). Effect of low ionic strength media on passive human red cell monovalent cation transport. $J$. of physiol. (London) 434:489-506.

Boron, WF; Boulpaep, EL (2004). Medical Physiology: A cellular and molecular Approach. Elsevier/Saunders.

Bouyer, G; Thomas, S; Egée, S (2012). Patch-Clamp Analysis of Membrane. In Kaneez, FS (ed.) 
Transport in Erythrocytes. Patch Clamp Technique, ISBN: 978-953-51-0406-3.

Chen, J; Minoura, N; Tanioka, A (1994). Transport of pharmaceuticals through silk fibroin membranes. Polymer 35:2853-2856.

Giese, AC (1963). Movement of solutes through the cell membrane in response to a concentration gradient. In Saunders, WB (ed.) Cell physiology, $2^{\text {nd }}$ ed. Philadelphia

Kee, JL; Paulanka, BJ (1994). Fluids and Electrolytes with Clinical Applications. Delmar Publ. Albany, NY.

Manalis, RS (1996). Water and solute movement through RBC membranes. In Glase, JC (ed.) Tested studies for laboratory teaching, 17:99116. Proceedings of the $17^{\text {th }}$ Workshop/Conference of the Association for Biology Laboratory Education (ABLE).

Nepal, O; Rao, JP (2011). Haemolytic effects of hypoosmotic salt solutions on human erythrocytes. Kathmandu Uni. Med. J. 34 (2):35-39.

Okolue, BN; Ekeocha, CI; Ikeaka, BI (2014). Study of the effect of $\mathrm{pH}$ and supporting electrolytes on the permeation of ions, through a polymeric membrane. Chem. Soc. Nig. 39 (2): 40-43

Ramirez, P; Alcaraz, A; Mafe, S; Pellicer, J (1999). pH and supporting electrolyte concentration effects on the passive transport of cationic and anionic drugs through fixed charge membranes. $J$. Membr. Biol. 161:143-155.

Rasia, M; Bollini, A (1998). RBC shape as a function of medium's ionic strength and $\mathrm{pH}$. Biochim. Biophys. Acta, 1372:198-204.

Sherwood, L; Klandorf, H; Yancey, PB (2013). Animal Physiology from Genes to Organisms, $2^{\text {nd }}$ ed. Thomson Brooks/Cole, California.

Sowemimo-Coker, S (2002). RBC haemolysis. Transf. Med. Rev. 16:146-60

Strand, FL (1983). The plasma membrane as a regulatory organelle. Physiology: A Regulatory Systems Approach, $2^{\text {nd }}$ ed. MacMillan, New York. Pp 49-67.

Yawata, Y (2003). Cell Membrane: The RBC as a Model. Wiley-VCH. 